\title{
Pollen analysis of present-day striped hyena (Hyaena hyaena) scats from central Iran: Implications for dryland paleoecology and animal paleoethology
}

\author{
Morteza Djamali a,b,*, Marjan Mashkour ${ }^{\mathrm{c}}$, Hossein Akhani ${ }^{\mathrm{d}}$, Dahvya Belkacem ${ }^{\mathrm{a}}$, Belinda Gambin ${ }^{\mathrm{e}}$, \\ Michelle Leydet ${ }^{\mathrm{a}}$, Nafiseh Samadi ${ }^{\mathrm{d}}$, Margareta Tengberg ${ }^{\mathrm{c}}$, Emmanuel Gandouin ${ }^{\mathrm{a}}$ \\ a Institut Méditerranéen de Biodiversité et d'Ecologie - IMBE (Aix Marseille Univ, Avignon Université, CNRS, IRD), Europôle de l'Arbois, 13545 Aix-en-Provence, France \\ ${ }^{b}$ Iranian National Institute for Oceanography and Atmospheric Sciences (INIOAS), 3 Etemad Zadeh St., Fatemi Ave., 1411813389 Tehran, Iran \\ ' Unité Archéozoologie, Archéobotanique: Sociétés, Pratiques et Environnements, (AASPE), Muséum national d'Histoire naturelle, CNRS (Centre National de la Recherche Scientifique), Case postale \\ 56, 55 rue Buffon, 75005 Paris, France \\ ${ }^{\mathrm{d}}$ Halophytes and C4 Plants Research Laboratory, Department of Plant Sciences, School of Biology, College of Sciences, University of Tehran, P.O. Box 14155-6455, Tehran, Iran \\ e Institute of Earth Systems, University of Malta, Msida, MSD 2080, Malta
}

Article history:

Received 19 June 2020

Accepted 29 June 2020

Available online $\mathrm{xxxx}$

Keywords:

Commensalism

Coprolite

Feces

Palynology

Late Quaternary

SW Asia

\begin{abstract}
A B S T R A C T
The striped hyena is the largest living omnivorous scavenger in SW Asia. It generally lives in semi-arid desert steppe regions, often denning in small caves, rock shelters, and burrows close to human settlements. Bone fragments of wild and domestic animals and desiccated scats are frequently found in the hyena dens. In this study, eight striped hyena desiccated scats were subjected to pollen analysis. All scats were rich in pollen and the exine was well-preserved with no visible sign of corrosion. Pollen spectra revealed interesting information on the regional and local vegetation, as well as the foraging behavior and diet of the animal. They reflected an array of different landscapes ranging from natural/semi-natural xerophytic desert steppes, agricultural fields, and grazing pastures. Some scats contained certain pollen taxa very rarely observed in wetland sediments, indicating the high potential of hyena "copropalynology" in providing detailed information on the past floristic composition of the landscape. When comparing with archeobotanical data from the area, the hyena scat assemblages show that the general physiognomy of the landscape has remained almost unchanged since the 6th millennium B.C., with only minor changes in the composition or density of the woody components of the desert steppe. As most of the Holocene fossil coprolites in archeological and paleontological sites of SW Asia would have been left by striped hyena, the study of the modern analogs of such accumulations in extant hyena dens is helpful to correctly interpret the fossil faunal assemblages to reconstruct the paleolandscapes, land-use change, and animal paleoethology.
\end{abstract}

\section{Introduction}

In drylands, where wetland systems are hard to find, alternative paleoenvironmental archives have been explored by paleoecologists. Among these, the organo-sedimentary structures such as packrat middens, bat guanos, and coprolites have been very informative (Scott, 2000; Pearson and Betancourt, 2002; Carrión et al., 2006). Coprolite remains, originating mainly from carnivores, constitute one of the most attractive materials for Quaternary paleoecology and have been increasingly analyzed by palynologists around the world (Scott et al., 2003;

* Corresponding author at: Institut Méditerranéen de Biodiversité et d'Ecologie - IMBE (Aix Marseille Univ, Avignon Université, CNRS, IRD), Europôle de l'Arbois, 13545 Aix-enProvence, France.

E-mail address: morteza.djamali@imbe.fr (M. Djamali).
Carrión et al., 2007; Argant and Philippe, 2011; Djamali et al., 2011). Their growing use by palynologists has led some scholars to use the term "copropalynology" to refer to this new sub-discipline in palynology (Argan, 2014). Most of the well-preserved coprolites found in paleontological and archeological contexts are of carnivorous origin, mainly belonging to Hyaenidae family (Horwitz and Goldberg, 1989; Argant and Philippe, 2011; Diedrich, 2012a). Due to the absolute dominance of hyena coprolites in the Pleistocene deposits of Eurasia and Africa, Hunt and Lucas (2019) define a biogeographic/taphonomic province that they name "Hyenacoprus province" as opposed to "Castrocorpus province" of N.- and S. America, the latter being dominated by herbivore coprolites. Attribution of coprolites to hyenas has been based on: (i) morphological analogies with modern hyena droppings, (ii) association with hyena bones, and more recently (iii) identification of hyena ancient DNA (Horwitz and Goldberg, 1989; Bon et al., 2012; Diedrich, 
2012a; Fourvel and Fosse, 2017). It seems that social and denning behavior of hyenas defecating on the same latrine sites and the high content of hydroxyapatite in their feces, facilitating the consolidation and fossilization, are the main factors for their good preservation in Quaternary sediments (Hunt and Lucas, 2019). Bone remains found in hyena coprolite-bearing Pleistocene deposits of Eurasia and Africa suggest that they probably belong to the extant spotted hyena, i.e., Crocuta crocuta (Erxleben, 1777) or its extinct subspecies called the "cave hyena" Crocuta crocuta subsp. spelaea (Goldfuss, 1823) (Yll et al., 2006; Argant and Philippe, 2011; Bon et al., 2012; Diedrich, 2012b). However, the presence of striped hyena or Hyaena hyaena (Linnaeus, 1758) coprolites has also been reported in some archeological sites in the Eastern Mediterranean region (Horwitz and Goldberg, 1989; Mashkour 2004a). Although no palynological study has been performed on these latter coprolites, their macromorphological, mineralogical, and petrographic examinations have yielded ample paleoenvironmental information. The striped hyena fossil fecal material can thus be potentially interesting for paleoecological investigations in semi-arid to arid regions located within the distribution range of the species (Fig. 2a).

Hyena coprolites have been reported from Iranian caves (Djamali et al., 2011). In the Wezmeh Cave, located in the Zagros Mountains in western Iran, a copropalynological analysis of hyena fossil feces has revealed a lot of information on the regional vegetation as well as the local floristic composition of the landscape, through the detection of some rare endemic plants (Djamali et al., 2011). Archeozoological identifications of bone remains from the same cave strongly suggest the dominance of the rests of spotted hyena, although the presence of striped hyena is not excluded (Mashkour et al., 2008; Monchot, 2008). The latter species has also been documented from other Paleolithic sites of Zagros (Turnbull, 1975; Marean and Kim, 1998). With the decline of the spotted hyenas at the onset of the postglacial period (Mashkour et al., 2008), striped hyenas gradually became the largest dominating scavenger in the dry landscapes of SW Asia. It is thus logical to assume that during the terminal Pleistocene to Holocene, hyena remains belong to the latter species.

This study is the first copropalynological analysis of modern striped hyena scats recovered directly from a hyena den complex in the circumdesert areas of central Iran. The hyena den of Kaftar Khun (Fig. 1) was surveyed and sampled for its faunal remains, in order to understand the diet and foraging behavior of the animal in present-day dry landscapes of central Iran (Monchot and Mashkour, 2010). The aims of this study are to evaluate the potential of the striped hyena scats: (i) to incorporate and preserve pollen grains, (ii) to reflect their surrounding vegetation and flora, (iii) to reveal their foraging behavior in relation to natural ecosystems and human activities.

\section{Setting}

\subsection{The site}

Kaftar Khun (also "Kaftārkhun" or "Kaftār Khun" in Persian) paleotravertine is located at about $5 \mathrm{~km}$ to the southwest of the city of Kashan in central Iran $\left(33^{\circ} 54^{\prime} 19^{\prime \prime} \mathrm{N}, 51^{\circ} 22^{\prime} 20^{\prime \prime} \mathrm{E}, 1190 \mathrm{~m}\right.$ a.s.l.). Geologically, it is one of a series of eroded fossil travertine and tufa deposits formed along a fault system on the eastern foothills of the Karkas Mountains in the west-central Iran (Biglari, 2004; Heydari et al., 2009). The Kaftar Khun travertine formed along the central segment of the active Kashan fault and no longer has any active spring (Berberian et al., 2012). The site displays several small hollows and rock shelters which have harbored, until very recently, an active striped hyena den complex (Heydari et al., 2009; Monchot and Mashkour, 2010). Indeed, etymologically, Kaftar Khun is composed of "Kaftar" (Kaftār) meaning "hyena" and "Khun" (Khūn) meaning "house" in Persian. The Kaftar Khun hyena dens were visited in several occasions from 2003 to 2005 and many bone fragments and desiccated scats were collected and identified (Mashkour, 2004a, 2004b; Monchot and Mashkour, 2010).
Unfortunately, over the past 15 years the intensive mining activities (to exploit the travertine deposits), along with the construction of a poultry house and a horse stable, have all contributed to the destruction of the site and its surrounding environment, forcing hyenas to abandon their dens.

Kaftar Khun ( $33^{\circ} 54^{\prime} 18.72^{\prime \prime} \mathrm{N}, 51^{\circ} 22^{\prime} 20.46^{\prime \prime} \mathrm{E}, 1192 \mathrm{~m}$ ) is located close to the well-known archeological site of Tepe Sialk in the vicinity of Kashan. This site, composed of two main mounds ("South Mound" and "North Mound"), displays a succession of cultural phases from Late Neolithic to Classical Antiquity (ca. 6200 BC-550 BC) (Ghirshman, 19381939 ) interrupted by recurrent abandonments related to paleoearthquakes and climatic changes (Berberian et al., 2012). Archeobotanical and archeozoological studies of the botanical and faunal materials, collected during the 2003-2005 excavation seasons of Sialk, reveal preliminary information on the plant and animal economy during the Neolithic to Iron Age periods (Mashkour, 2004a, 2004b; Tengberg, 2004; Shirazi and Tengberg, 2012; Ilkhani et al., 2019; Mashkour et al., 2019). They show: (i) significant cultivation of cereals including both wheat (Triticum spp.) and barley (Hordeum vulgaris), (ii) intensive exploitation over millennia of woods mainly for fuel (both riparian and desert steppe woody species), (iii) beginning of arboricultural activities during the Iron age, and (iv) presence of steppe animals like gazelles and Persian indicating an arid environment. The availability of these natural plant and animal resources, as well as spring water resources for cereal farming, close to the sites have been two major factors attracting pre-historic human communities to these fringes of the Central Iranian Great Desert (Berberian et al., 2012). The presence of water resources has been also demonstrated in another nearby archeological site of Shamshirgah, an Iron Age settlement on the outskirt of the central desert (Mashkour and Fahimi, 2019).

\subsection{Climate and vegetation}

Based on data from the meteorological station of Kashan (Fig. 1c), located a few kilometers from the site, the area has an Irano-Turanian pluviseasonal continental climate. This bioclimate, equivalent to Mediterranean pluviseasonal continental in the Mediterranean region, dominating the central part of the Iranian plateau is characterized by high continentality ( $M-m \geq 21$, where $M$ is the mean of maxima of warmest and $m$ is the mean of minima of coldest months), very scarce precipitation during the growing season $(<200 \mathrm{~mm} / \mathrm{yr})$ and a long dry season lasting up to 8 months (Djamali et al., 2011; Rivas-Martinez et al., 2011). Under the control of such a harsh bioclimate, the vegetation on the eastern foothills of the Karkas mountains falls in the "xerophytic desert steppe" belt dominating elevations $<1500 \mathrm{~m}$ in central Iran (Dehghani et al., 2017). Here, the vegetation is composed of a typical Irano-Turanian Artemisia steppe (mostly represented by A. dumosa, a name which is replaced by A. sieberi in the Flora Iranica (Podlech, 1986, 2013). The open dwarf-shrub steppe is well developed on the well-drained alluvial plains with numerous xerophytic and tragacanthic herbaceous species and co-dominated by xerophytic shrubs/dwarf shrubs of Ephedra spp., Zygophyllum atriplicoides, Pteropyrum aucheri, and subshruby Astragalus species. The vegetation is very rich in ephemerals and xerophytic species, mainly belonging to Asteraceae, Brassicaceae, Boraginaceae, Papaveraceae, and Poaceae. Further to the east, the vegetation is either psamophytic developed on the vast sand dunes or halophytic developed in the saline depressions both surrounding the city of Kashan or gypsophytic formations on gypsum hills in the east of Kashan. In the vicinity of the Kaftar Khun hyena den complex, the sparse steppe vegetation is dominated by Artemisia sp., Astragalus spp., Acantholimon spp., Bromus tectorum, Noaea mucronata, Cleome coluteoides, Peganum harmala, Scariola orientalis, and Stachys inflata indicating an overgrazed desert steppe vegetation. 


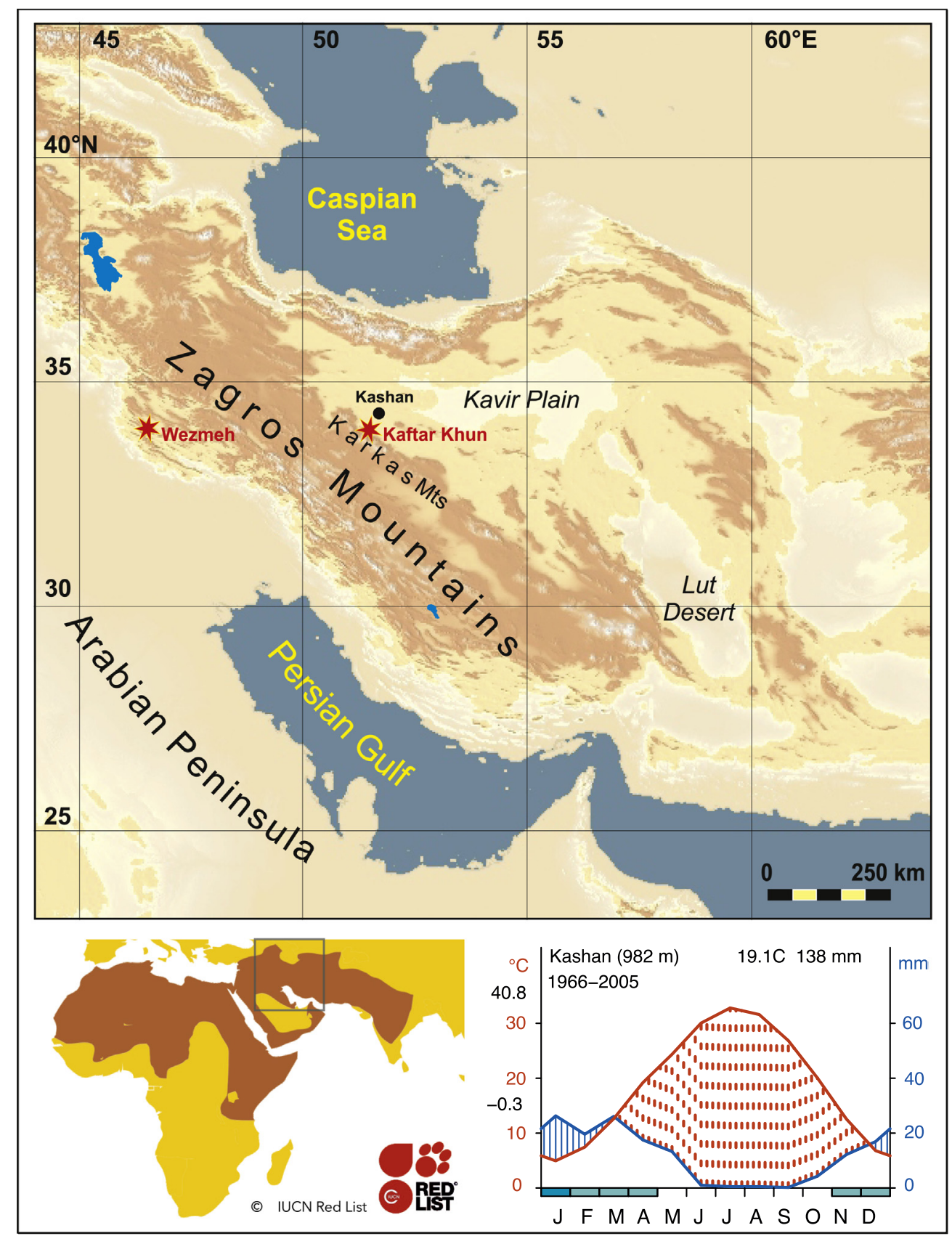

Fig. 1. a. Geographical position of the study site (Kaftar Khun) at the edge of central Iranian Plateau. b. The IUCN map for worldwide distribution of Hyaena hyaena (in dark brown) in Eurasia and Africa. c. Climate diagram based on Iran Meteorological Organization data from the city of Kashan. (For interpretation of the references to color in this figure legend, the reader is referred to the web version of this article.)

\subsection{Striped hyena in Iran}

Hyaena hyaena (Linnaeus, 1758) is the only extant species of hyaenidae in Iran (Firouz, 2005). The Striped hyena, a "near-threatened" species in the IUCN Red List (AbiSaid and Dloniak, 2015), is also considered vulnerable in this country, suffering from the loss of its natural habitats, less availability of carcasses, persecution by local human populations, and vehicle collision (Tourani et al., 2012). Studies of habitat evaluation of the species show that open landscapes dominated by Artemisia steppes, with the presence of limestone outcrops providing rock shelters, are the ideal environmental conditions for denning activities (Rezaei et al., 2017). Striped hyenas are nocturnal foragers, mostly scavenging on remains of other animals left by large carnivores; however, they can occasionally hunt small animals such as lizards, rabbits, rodents, and insects (Rieger, 1979; Wagner, 2006; Monchot and Mashkour, 2010). Unlike spotted hyenas, the striped hyenas rarely form groups and are mostly solitary animals, occasionally foraging in pairs (Fig. 2). They are adapted to arid and semi-arid conditions but need to regularly drink from water resources located within $10 \mathrm{~km}$ of their habitats (Rieger, 1979; Wagner, 2006). Striped hyenas can be considered as omnivorous scavengers because they also feed on fruits, vegetables, and occasionally human refuse (Rieger, 1979; Wagner, 2006). The availability of these plant food resources, as well as the livestock carcasses around human settlements, is increasingly drawing striped hyenas to peri-urban areas, habitations, and landfills (Monchot and Mashkour, 2010; Shamoon and Shapira, 2019) which is not necessarily beneficial to the survival of this threatened species (Tourani et al., 2012). 

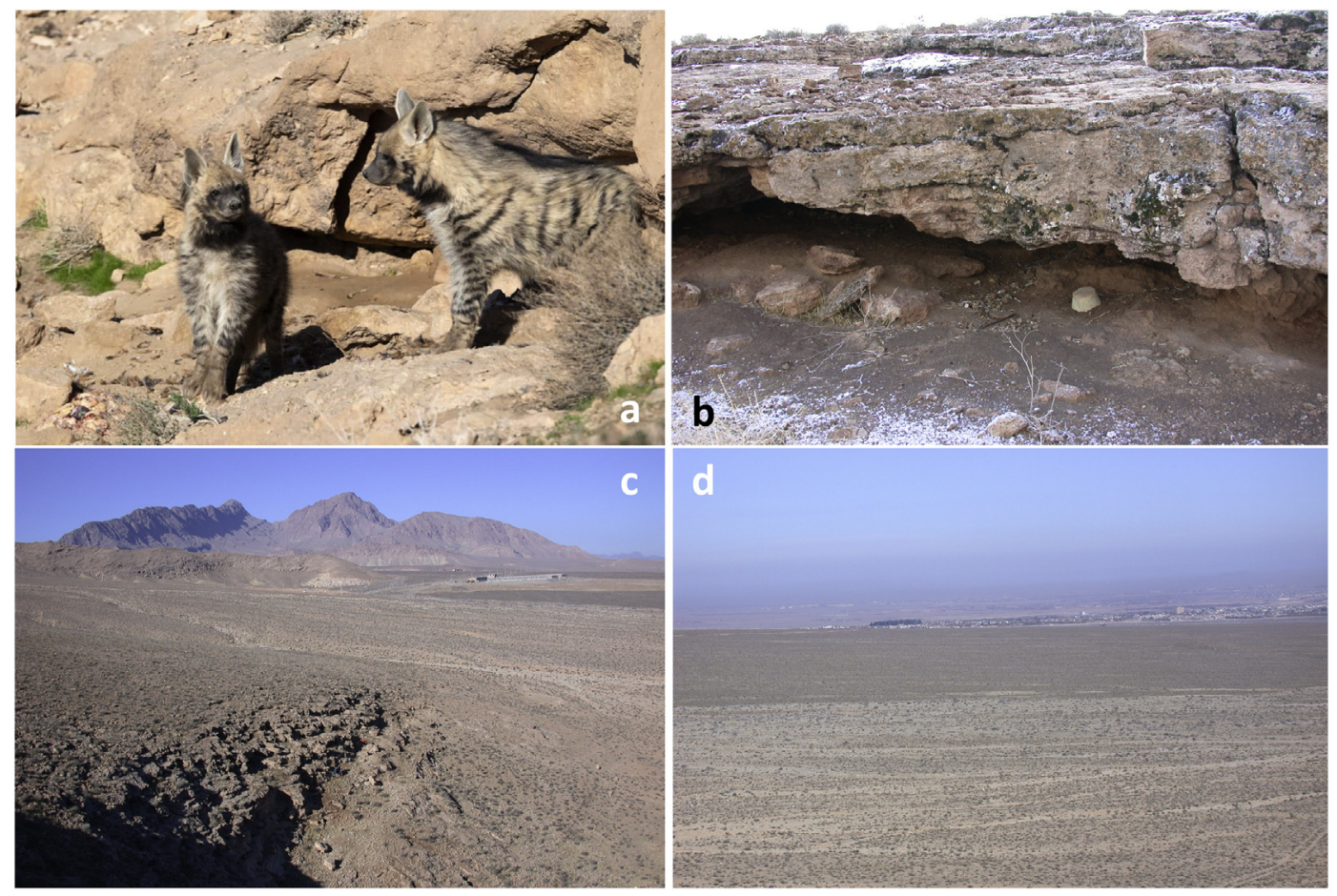

Fig. 2. a. Two striped hyenas recently photographed in central Iran (not Kaftar Khun). b. Den complexes are mostly found in rock shelters formed in limestone outcrops. c. The position of the den complex in a travertine outcrop, photo looking north. d. Photo looking northwest: foreground shows xerophytic desert Artemisia steppe and background shows the suburbs of the city of Kashan and the central Iranian desert. Photo a is courtesy of wildlife photographer M. Saeed Davari. Photos, b, c, and d by MM.

\section{Materials and methods}

Some 30 modern hyena scats were collected from the Kaftar Khun rock shelter and put into small plastic bags in 2005 by the second author. Eight of the best-preserved scats were selected for pollen analysis (samples KK1-KK8, Table 1, Fig. 3). After cleaning their surfaces, samples were prepared using the standard extraction technique described by Moore et al. (1991). One Lycopodium tracer tablet (Batch 1030 , Lund University) was added to each sample before treatment, to calculate the pollen concentrations in grains/g of dry material (Stockmarr 1971). A minimum of 207 pollen grains were identified and counted under $\times 500$ magnification using a Zeiss Axiolab 5 light microscope equipped with Phase Contrast. The Iranian pollen reference collection hosted at the Institut Méditerranéen de Biodiversité et d'Ecologie (Aixen-Provence, France), as well as the pollen atlases of Reille (1992, 1995, 1998), Bonnefille and Riollet (1980), and van Zeist and Bottema (1977) were consulted for identification of difficult pollen grains.

Table 1

Size measurements and some pollen values of the studied desiccated hyena scats of Kaftar Khun.

\begin{tabular}{|c|c|c|c|c|c|c|}
\hline \multirow[t]{2}{*}{ Sample } & \multicolumn{2}{|l|}{ Size } & \multirow{2}{*}{$\begin{array}{l}\text { No. } \\
\text { pollen } \\
\text { types }\end{array}$} & \multirow{2}{*}{$\begin{array}{l}\text { Total } \\
\text { Pollen } \\
\text { counts }\end{array}$} & \multirow{2}{*}{$\begin{array}{l}\text { Weight } \\
\text { of } \\
\text { treated } \\
\text { sample } \\
(\mathrm{g})\end{array}$} & \multirow{2}{*}{$\begin{array}{l}\text { Pollen } \\
\text { concentration } \\
\text { No. } / g\end{array}$} \\
\hline & $\begin{array}{l}\text { Length } \\
(\mathrm{mm})\end{array}$ & $\begin{array}{l}\text { Breadth } \\
(\mathrm{mm})\end{array}$ & & & & \\
\hline KK1 & $\mathrm{N} / \mathrm{A}$ & $\mathrm{N} / \mathrm{A}$ & 16 & 428 & 0.5 & 31,982 \\
\hline КK2 & 26 & 23 & 20 & 377 & 1.1 & 52,538 \\
\hline KK3 & 39 & 20 & 25 & 207 & 1.1 & 14,694 \\
\hline KK4 & 70 & 21 & 27 & 380 & 1.5 & 10,845 \\
\hline KK5 & 28 & 31 & 29 & 283 & 1.3 & 55,345 \\
\hline KK6 & 87 & 26 & 33 & 428 & 1.8 & 17,896 \\
\hline KK7 & 31 & 28 & 27 & 344 & 2.7 & 6881 \\
\hline KK8 & 53 & 34 & 16 & 379 & 1.9 & 70,485 \\
\hline
\end{tabular}

A pollen percentage diagram was created in the R package "rioja" (Juggins, 2019). Principal Component Analysis (PCA) was performed on $\mathrm{n}=8$ (number of individuals/observations) by $\mathrm{p}=74$ (number of taxa/variables) pollen matrix of percentages. This analysis allows for the extraction of important information from a multivariate data table (containing individuals/observations described by multiple intercorrelated quantitative variables), it expresses this information as a condensed set of new variables called principal components that can potentially reveal environmental gradients. These new variables correspond to a linear combination of the originals. Thus, PCA reduces the dimensionality of a multivariate data to two or three principal components, that can be visualized graphically, with minimal loss of information. Before PCA analysis, data were square-root transformed to stabilize the variance. Rare taxa, i.e. those present in only one sample (or with a relative abundance consistently $<1 \%$ ), were removed from the analysis.

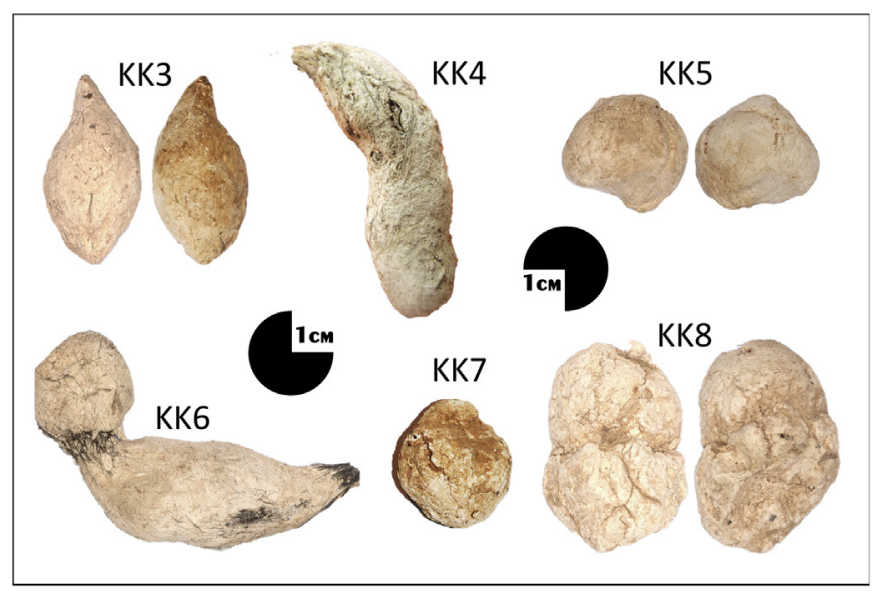

Fig. 3. Pictures of six of the hyena scats studied in this paper. 
Along with the PCA, a Hierarchical Clustering on Principal Components (HCPC) was also performed. The goal of HCPC is to identify groups (i.e., clusters) of similar objects within the data set (using the Ward's criterion on the selected principal components). PCA analysis was performed using "ade4" R package (Dray et al., 2020) and presented in Fig. 5. The results were then visualized using the R packages "magrittr" (Bache and Wickham, 2014) and "factoextra." (Kassambara, 2020) Furthermore, Cluster Analysis was applied to the PCA results using "FactoMineR" package (Husson et al., 2020). "Another PCA biplot created in "vegan" (Oksanen et al., 2019) with more illustrative details was put in the Supplementary Materials. The climate diagram, in Fig. 1c, was created in the "climatol" package (Guijarro, 2019). All R packages were run in RStudio version 3.5.3 (RStudio Team,2015).

\section{Results and discussion}

Samples were relatively rich in pollen, with the pollen concentration ranging between 6881 to 70,485 pollen/g of dried fecal material (Table 1). Pollen counts varied between 207 and 428 per slide (Table 1), with all pollen grains being included in the total pollen sum to calculate percentages. The pollen percentage diagram is illustrated in Fig. 4 and the PCA biplot of the variables (taxa) versus samples is provided in Fig. 5. Overall the samples are generally reflecting an open landscape, with herbaceous pollen dominating the spectra and arboreal pollen comprising very low percentages of the total pollen sum (Fig. 4). A PCA-based non-constrained hierarchical classification helped define clusters of samples based on similarity of their pollen

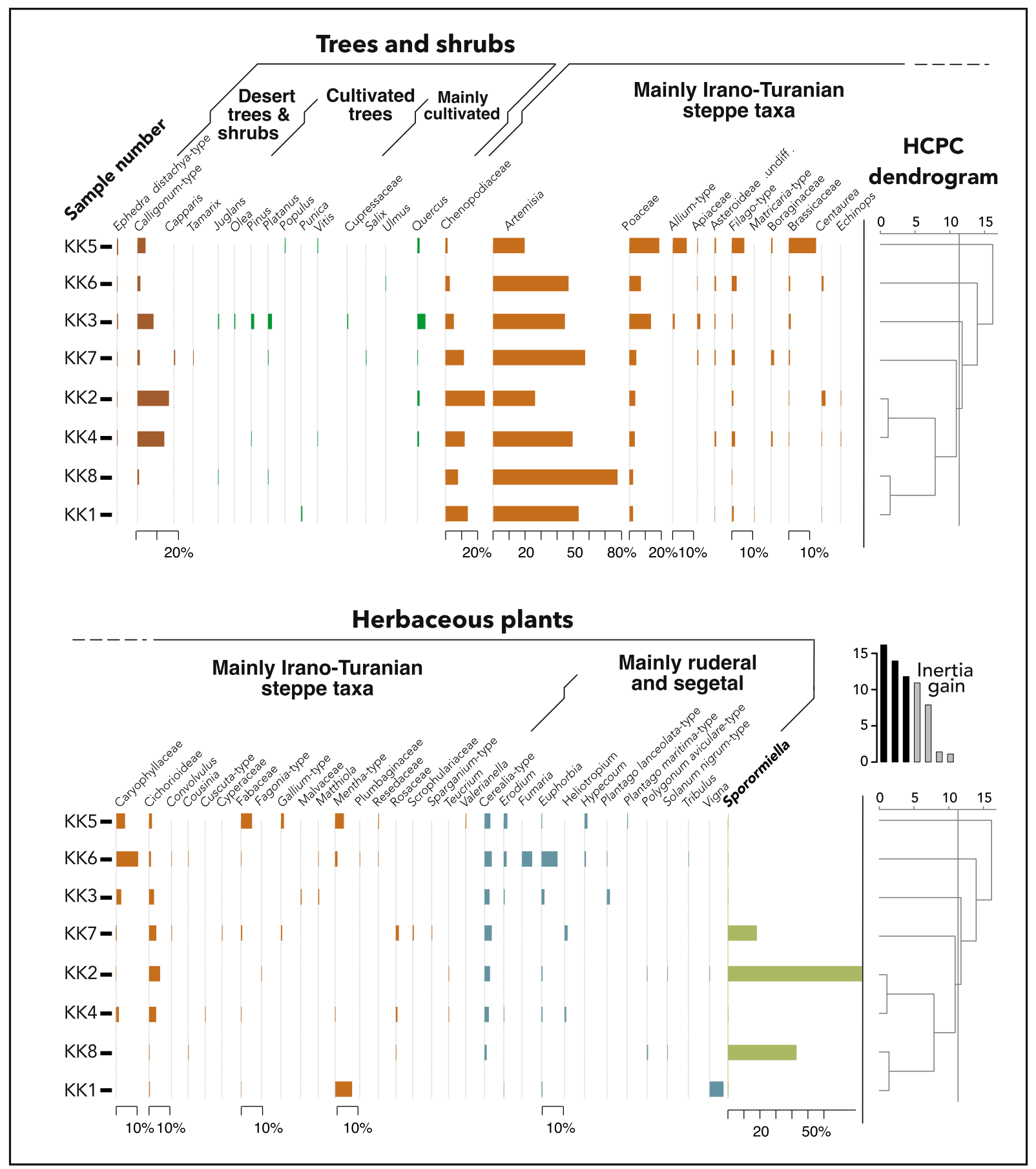

Fig. 4. Pollen percentage diagram of the eight hyena scats. Sporormiella percentage in sample KK2 is $>2900 \%$ calculated based on total pollen sum. 


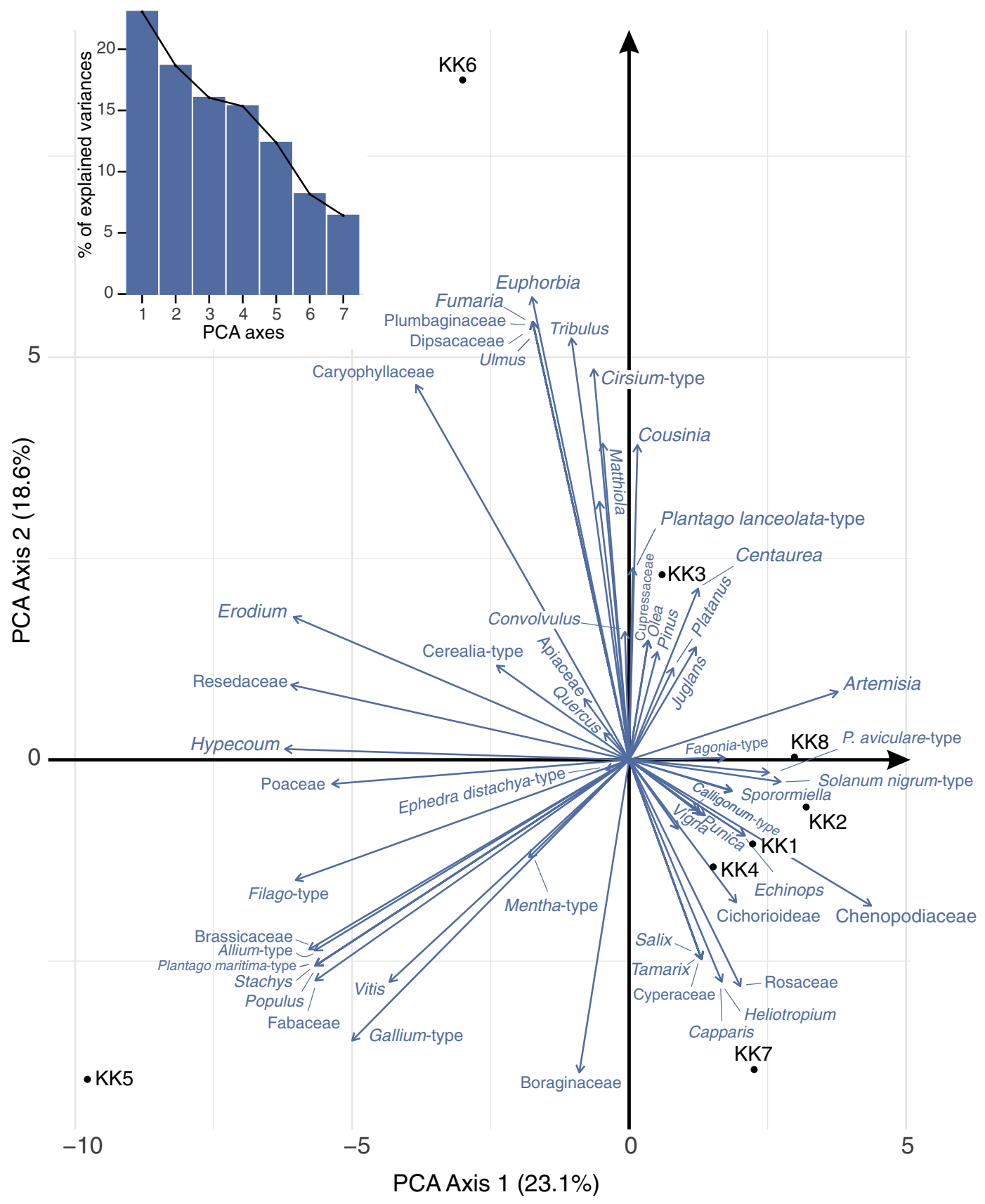

Fig. 5. PCA biplot comprising the main pollen types (variables) found in hyena scats K1 to K8 (samples).

percentages (right side of the pollen diagram, Fig. 4). The PCA biplot in Fig. 5 shows how the eight projected samples are explained by different pollen taxa and along two first PCA Axes.

PCA Axis 1 and Axis 2 together explain 23.1\% and 18.6\% of variance and indicate that half of the samples (KK1, 2, 4, and 8) present a relatively homogeneous pollen assemblage and group together in the positive side of PCA Axis 1 (KK1, 2, 4, and 8). This is also evident in the HCPC dendrogram lower cluster (Fig. 4). These are dominated by Artemisia and Chenopodiaceae s. str. Please note that in this paper, we prefer to use the name Chenopodiaceae despite the fact that Angiosperm Phylogeny Group Classification (Byng et al., 2016) suggests a broader sense by using Amaranthaceae. Our argument is that the pollen structure of Chenopodiaceae represents arid habitat in contrast to Amaranthaceae s. str., in which many species are of tropical origin. The whole cluster of $\mathrm{KK} 1,2,4$, and 8 indicate the hyenas foraging in the natural dry steppes. The negative side of Axis 1 is more difficult to interpret because the pollen types with highest contributions are of both natural and anthropogenic origin (e.g., Resedaceae and Brassicaceae). PCA Axis 2 opposes sample KK5 and 7 in the negative side and sample KK6 in the positive side. While KK7 is characterized by aquatic plants and riparian trees (Sparganium-type, Cyperaceae, and Salix and Tamarix), suggesting hyenas drinking from a water source (spring, qanat etc.), KK5 appears more characterized by anthropogenic species (e.g., Plantago maritimatype, Vitis, and Populus). In contrast, sample KK6 clearly indicates a very anthropic landscape, possibly the abandoned arable lands and/or overgrazed lands in the vicinity of human habitations (e.g., Tribulus and Euphorbia). Any further interpretation of the other PCA biplot axes may be an overinterpretation of data because according to the scree diagram (top left, Fig. 5), there is little difference between variances explained by axis 3 onwards. We thus propose that the HCPC 
results provide a better illustration to distinguish the dissimilarities between the different samples.

\subsection{Regional vegetation}

The pollen spectra of all the examined hyena scats are largely dominated by pollen taxa characteristic of an open dry landscape covered with an Irano-Turanian Artemisia steppe containing significant amounts of xerophytic shrubs and dwarf shrubs. Artemisia accounts for $50-80 \%$ of the total pollen sum except in samples KK2 and KK5 (Fig. 4). Poaceae and Chenopodiaceae (sensu Hernández-Ledesma et al., 2015 and not Byng et al., 2016) are the next most abundant pollen types accompanied with many other herbaceous plants with low pollen values. Pollen of desert trees/shrubs dominated by Calligonum-type constitute by far the most abundant arboreal pollen in most of the samples (0.8-15\%). Calligonum-type pollen is produced by two woody genera of Polygonaceae family, i.e., Calligonum spp. and Pteropyrum spp. (excluding P. naufelum) (Doostmohammadi et al., 2019). The latter species has its own characteristic morphology. While Pteropyrum, as a C3 plant, temporarily dominates seasonal water runnel and alluvial soils near Kashan and the eastern flank of Karkas Mountains, Calligunum, a C4 lineage, is a psamophytic genus with several species growing in desert dunes in lower altitudes. Both shrubs are not, however, halophytic and prefer well-drained substrates. Ephedra distachya-type pollen is also a background pollen, present in almost all spectra but with very low values $(<1 \%)$. Nowadays, Ephedra spp. are found in the foothills of the Karkas mountains at lower elevations and gypsum hills in the southeastern parts of the region. The presence of Quercus pollen is interesting, showing that the values between 0.3 and $4 \%$ of oak pollen can highlight longdistant transport, mostly from the Zagros open oak forest located some $200 \mathrm{~km}$ to the west and brought by the prevailing westerly winds. Comparison of the pollen spectra of the Kaftar Khun hyena scats with the modern surface pollen spectra from a mountain-desert transect in north-central Iranian Plateau (Dehghani et al., 2017) indicates a surprisingly high similarity, with those spectra coming from the "xerophytic desert to semi-desert steppe" dominated by Artemisia dumosa on dry soils and Pteropyrum aucheri in dry river beds. In both cases Artemisia pollen varies between 40 and $80 \%$ and Chenopodiaceae and Poaceae pollen mostly remain around or under $10 \%$. The "xerophytic desert/semidesert" steppe vegetation belt is found between 800 and $1500 \mathrm{~m}$ (Dehghani et al., 2017), suggesting that the striped hyena foraging area is limited to this altitudinal range. This vegetation belt also covers vast areas on the southern foothills and alluvial plains of the Alborz Mountains in north-central Iran (Klein, 1994).

Anthracological investigations at the archeological site of Tape Sialk ( $8 \mathrm{~km}$ northwest of Kaftar Khun) reveal significant prehistoric exploitation of woody components of the xerophytic desert steppes of the region over millennia (Shirazi and Tengberg, 2012). The consumed woody taxa in the Sialk layers are dominated by a mixture of desert trees/shrubs (Haloxylon sp., Lycium sp.,) and riparian (Fraxinus sp., Elaeagnus angustifolia, Salix sp., Tamarix sp.) and montane cliff species (Celtis sp.). Absence of the charcoals of Pteropyrum/Calligonum and Ephedra, the main shrub pollen taxa found in the Kaftar Khun scat assemblages is noteworthy. It may be explained by: (i) once lower abundance of these taxa or their former extirpation from the landscape by humans, (ii) easier access to riparian species and Haloxylon sp., (iii) lower energetic values of Pteropyrum/Calligonum as fuel compared to other exploited species, and (iv) incomplete sampling of the archeological layers causing a bias in data. It should also be noted that Haloxylon pollen is difficult to distinguish from several other species of Chenopodiaceae and its pollen has certainly been grouped under this family in our pollen diagram.

\subsection{Anthropogenic imprints in pollen spectra}

Pollen types related to human activities are present in all the hyena scats and include cultivated (ornamental and fruit) trees, cereals, and pulses, segetal plants associated with cultivated fields and ruderal plants indicating disturbed soils and pastoral activities (Fig. 4). Diversity and abundance of these pollen types demonstrate that the hyenas had been living in a mosaic of environments mostly impacted by different human activities. Some of the pollen types (e.g., pastoral indicators $\mathrm{Eu}$ phorbia, Plantago lanceolata-type) have been sourced from vast seminatural ecosystems, such as the grazed/overgrazed xerophytic shrub steppes extended on the mountain slopes and alluvial plains far from the villages and cities. Others (crops and cultivated trees) are however, mostly limited to permanent settlements and urban/peri-urban areas. Some pollen types identified and quantified in the scats provide very specific information on agricultural crop types. Sample KK1, for instance, contains about $1 \%$ pollen of pomegranate (Punica), a very underrepresented tree in modern pollen rain (van Zeist et al., 2001) and samples KK1 and KK3 display pollen of Vigna cf. unguiculata or cowpea, a cultivated bean of West and/or East African origin (Xiong et al., 2016) nowadays grown in different parts of Iran including the study area. Cereals are also significantly present in most of the samples, a fact that is largely expected because dry and irrigated cereal farming is commonly practiced in the plain as well as the mountain areas around Kaftar Khun. Among the ruderal and segetal taxa, the presence of the pollen of Hypecoum and Fumaria, two rarely encountered pollen types in palynological samples is worth mentioning. Both Hypecoum pendulum L. and Fumaria asepala Boiss. were observed flowering in May 2015 by MD in Kamou village ( $30 \mathrm{~km}$ to southwest of Kaftar Khun). They are ruderal plants growing in abandoned fields, trampled soils, along water courses and roadsides and even in the fissures of paved sidewalks. Hypecoum pendulum also occurs in the Artemisia steppes. Erodium pollen, present in most of the samples, is produced by species such as E. cicutarium (L.) L'Hér., which is common in ruderal and semi-natural steppe soil, it was also observed in Kamou as a weed in the abandoned fields in May 2015. All samples contained the dung-associated fungal spores belonging to Sporormiella sp. The values varied from < 1\% (KK1, KK4, and KK7) to enormous amounts in KK2 (2920\% calculated based on the total sum of pollen grains excluding Sporormiella), indicating the significant presence of livestock in hyena foraging areas and the possible consumption of their entrails by hyenas.

Archeobotanical evidence from Sialk suggests that cereal farming (both wheat and barley) was practiced by human communities settled in the area since the Neolithic (6th millennium BCE), with possible grapevine cultivation at least since the Iron Age (Tengberg, 2004). The present-day mixture of diverse landscapes including natural/seminatural steppes, riparian systems, agricultural lands, orchards, pastures, and urban areas have thus been present in the area since the early-mid Holocene, leaving thousands of years for striped hyenas to adapt to their changing environment by humans.

\subsection{Paleoecological and paleoethological potential}

In general, pollen grains identified and counted in the examined scats were well-preserved and almost no traces of digestion by gastric acids of the animal could be observed, confirming similar observations from Africa (Scott et al., 2003). Pollen data of the eight examined hyena scats clearly reveal the strong potential of these fecal materials in: (i) reconstructing the natural/semi-natural ecosystems in local and regional scale, (ii) understanding human agro-pastoral activities, (iii) revealing the foraging behavior and diet of the striped hyenas, and (iv) detecting rare plant taxa.

Both the spotted and striped hyenas are very mobile animals traveling up to $20 \mathrm{~km} / 24 \mathrm{~h}$, mainly during the night (Wagner, 2006; Kolowski et al., 2007). The bone accumulation is, however, much more practiced by striped hyenas compared to spotted hyenas (Fourvel et al., 2015). The high mobility, combined with the proximity to human settlement areas, allows the striped hyenas to visit a diverse mosaic of landscapes more or less impacted by human activities. Several studies suggest that the hyena scat pollen spectra represent the whole area foraged by 
the animal and not only around the den site (Carrión et al., 2001; Scott et al., 2003). Indeed, the pollen can be added to a scat through multiple ways: (i) pollen settled on the food before ingestion, (ii) pollen deposited on the scat after defecation, (iii) pollen found inside the digestive tube of the herbivores, (iv) direct ingestion of flowers, (v) pollen found in drinking water, and (vi) pollen absorbed through cleaning by their rough tongues (Scott et al., 2003; Mohamed Ahmed et al., 2012). The latter process may have been underestimated as a recent study has observed that striped hyenas take time to clean each other in captivity, on average 1.15 min per day (Mohamed Ahmed et al., 2012). These diverse sources and processes of pollen ingestion can explain the abundant and diverse pollen flora encountered in hyena feces.

A number of studies indicate that while striped hyenas avoid direct contact with humans, they remain close to pastoral communities inside or outside the urban/peri-urban areas, which permits them to diversify their food resources (Fourvel and Mwebi, 2011). Osteological identifications of faunal assemblage of the Kaftar Khun den complex by Monchot and Mashkour (2010), shows that $84.6 \%$ of the identified specimens belong to domesticated animals with equids (horses, donkeys, and mules) comprising $72.1 \%$, followed by domestic cattle (8.1\%) and sheep/goat (3.0\%). This high percentage of domestic animal bone remains makes the authors suggest that the striped hyenas have become commensal animals. A recent study of the hyena population density and distribution in arid NW India also indicates that striped hyenas not only socially tolerate humans but take advantage of the availability of more food resources in human-dominated landscapes (Singh et al., 2014). In that study, the maximum number of animal detection was recorded at a distance between 1 to $3 \mathrm{~km}$ from human settlements. Availability of livestock carcasses and orchards are among the most important factors attracting the animal to habitations (Karami et al., 2006; Singh et al., 2010; Fourvel and Mwebi, 2011; Singh et al., 2014). Consuming the internal organs of domestic herbivores may be one of the most important ways of ingestion of pollen of segetal, ruderal and cultivated plants into the hyena scats. Finding the very rare pollen types in the Kaftar Khun fecal samples (see Punica, Hypecoum, and Fumaria; Fig. 4) has similarly been reported from the Wezmeh Cave in which rare plant taxa such as tulips (Tulipa spp.) have been documented (Djamali et al., 2011). Such pollen types are seldom found in sedimentary archives due to the taphonomic history (see e.g., the long pollen records from Lake Urmia, Djamali et al., 2008; pollen data accessible in the European Pollen Database: http://www.europeanpollendatabase.net/index.php). These findings suggest that hyena fossil scats are an important source of information in relation to the detailed floristic composition of steppe vegetation.

Both spotted and striped hyenas have played a significant role as omnivorous scavengers in the arid and semi-arid ecosystems of Eurasia and Africa during the Pleistocene. The role of the striped hyena has become increasingly important in SW Asia after the decline of the spotted hyenas at the end of the last glacial period (Horwitz and Goldberg, 1989; Mashkour et al., 2008). Although no striped hyena fossil coprolites have so far been reported from the Iranian Plateau, we believe that some recent coprolites found in the Wezmeh Cave in western Iran correspond to this species, judging from very high morphological similarities (cf. sample KK3 in Fig. 3 of this study to sample WC-2 ( $405 \pm 59$ cal. BP) in Fig. 2 in Djamali et al., 2011). The increasing number of archeological excavations in SW Asian caves and rock shelters are providing abundant faunal remains including hyena bones and coprolites (Mashkour et al., 2008; Scott et al., 2016). Our results show that the pollen encapsulated in these coprolites can be a major source of information on their environments, their foraging behavior and diet, as well as their interactions with human societies in the far and recent past. Biological investigation of modern hyena scats collected from different ecosystems across the region can help establish modern analogs for a robust interpretation of the data obtained from fossil fecal materials. Copropalynological investigations are only one of the many different bioarcheological techniques that can be applied to these precious fossil materials (Horwitz and Goldberg, 1989; Scott et al., 2016). Application of molecular studies of coprolites, further refines the attribution of coprolites to the lowest possible taxonomic levels (Bon et al., 2012; Bennett et al., 2016) and is complementary to their bioarchaeological study.

\section{Concluding remarks}

1. Like their spotted cousins, striped hyenas also leave feces that are rich in well-preserved pollen grains with great potential for paleoecological reconstructions.

2. Pollen grains in all the examined modern hyena scats were wellpreserved and of very different natural and anthropogenic sources.

3. All pollen assemblages revealed the general traits of the regional vegetation composed of a xerophytic desert steppe with sparse desert wood shrubs.

4. Abundance of cultivated, segetal, and ruderal pollen can provide invaluable information on the human agro-pastoral activities and land-use changes.

5. The mixture and diversity of pollen originating from both natural/ semi-natural ecosystems and anthroposystems, as well as the diversity of pollen ingestion processes, provides the possibility to obtain a detailed image of the foraging and dietary behavior of striped hyenas.

6. The studied hyena feces pollen assemblages clearly show a commensal behavior of the animal and its use of food resources provided by human activities.

7. Direct and indirect ingestion of flowers adds details to the reconstruction of the floristic composition of the vegetation in the foraging area of striped hyenas.

8. Analogy between the examined scats with some Holocene subfossil hyena scats suggest that striped hyena coprolites from archeological/paleontological sites can be of high potential in bioarchaeological and paleoenvironmental studies.

Supplementary data to this article can be found online at https://doi. org/10.1016/j.revpalbo.2020.104277.

\section{Declaration of Competing Interest}

\section{None.}

\section{Acknowledgment}

We wish to thank Fereidoun Biglari, Abbas Etemad, Hamid Fahimi, and Saman Heydari-Guran for the organization and valuable assistance during the field works. We are also deeply indebted to Mr. Saeed Davari who kindly provided us with hyena photographs. Frédéric Guiter is also thanked for preparing photographs from the hyena scats. This work was funded by UMR 7209 AASPE and the LIA - HAOMA project of Centre National de la Recherche Scientifique (CNRS, France) a four-year grant allocated to the international collaborative project, as well as the French-Iranian joint scientific cooperation "Gundishapur Program 2016" project entitled "KECO-INO" funded by French Ministry of Europe and Foreign Affairs and Ministry of Higher Education, Research and Innovation in partnership with Center for International Scientific Studies and Collaboration (CISSC), Iranian Ministry of Research, Science and Technology.

\section{References}

AbiSaid, M., Dloniak, S.M.D., 2015. Hyaena hyena. The IUCN Red List of Threatened Species 2015: e.T10274A45195080.

Argan, J., 2014. La copropalynologie: coprolithes et paléoenvironnements. Bull. Mus. Anthropol. Monaco 54, 39-44.

Argant, J., Philippe, M., 2011. L'analyse pollinique des coprolithes: Un outil pour la reconstruction du paléoenvironnement. Quaternaire 4, 307-318.

Bache, S.M., Wickham, H., 2014. Package 'Magrittr': A Forward-Pipe Operator for R. URL. https://cran.r-project.org/web/packages/magrittr/index.html. 
Bennett, E.A., Gorgé, O., Grange, T. 2016. Coprolites, paleogenomics and bone content analysis. In: Fernández-Jalvo, Y., Geigl, E.-M., King, T., Yepiskoposyan, L., Andrews, P. (Eds.), Azokh Cave and the Transcaucasian Corridor. Springer, Dordrecht, pp. 271-286.

Berberian, M., Shahmirzadi, S.M., Nokandeh, J., Djamali, M., 2012. Archaeoseismicity and environmental crises at the Sialk mounds, Central Iranian Plateau, since the Early Neolithic. J. Archaeol. Sci. 39, 2845-2858.

Biglari, F., 2004. The Preliminary Survey of Paleolithic Sites in the Kashan region. In: Shahmirzadi, S.M. (Ed.), The Silversmiths of Sialk (Sialk Reconsideration Project), Report No. 2. Archaeological Research Center, Iranian Cultural Heritage Organization, Tehran, pp. 151-168 (In Farsi).

Bon, C., Berthonaud, V., Maksud, F., Labadie, K., Poulain, J., Artiguenave, F., Wincker, P., Aury, J.-M., Elalouf, J.-M., 2012. Coprolites as a source of information on the genome and diet of the cave hyena. Proc. R. Soc. B 279, 2825-2830.

Bonnefille, R., Riollet, G., 1980. Pollen des savanes d'Afrique Orientale. CNRS Editions, Paris.

Byng, J.W., Chase, M.W., Christenhusz, M.J.M., Fay, M.F., Judd, W.S., Mabberley, D.J., Sennikov, A.N., Soltis, D.E., Soltis, P.S., Stevens, P.F., Briggs, B., Brockington, S., Chautems, A., Clark, J.C., Conran, J., Haston, E., Moller, M., Moore, M., Olmstead, R., Perret, M., Skog, L., Smith, J., Tank, D., Vorontsova, M., Weber, A., Angiosperm, Phylogeny G., 2016. An update of the Angiosperm Phylogeny Group classification for the orders and families of flowering plants: APG IV. Bot. J. Linn. Soc. 181, 1-20.

Carrión, J.S., Riquelme, J.A., Navarro, C., Munuera, M., 2001. Pollen in hyaena coprolites reflects late glacial landscape in southern Spain. Palaeogeogr. Palaeoclimatol. Palaeoecol. 2705, 1-13.

Carrión, J.S., Scott, L., Marais, E., 2006. Environmental implications of pollen spectra in bat droppings from southeastern Spain and potential for palaeoenvironmental reconstructions. Rev. Palaeobot. Palynol. 140, 175-186.

Carrión, J.S., Scott, L., Arribas, A., Fuentes, N., Gil-Romera, G., Montoya, E., 2007. Pleistocene landscapes in central Iberia inferred from pollen analysis of hyena coprolites. J. Quat. Sci. 22, 191-202.

Diedrich, C.G., 2012a. Typology of ice age spotted hyena Crocuta crocuta spelaea (Goldfuss, 1823) coprolite aggregate pellets from the European late Pleistocene and their significance at dens and scavenging sites. New Mex. Mus. Nat. Hist. Sci. Bull. 57, 369-377.

Diedrich, C.G., 2012b. An Ice Age spotted hyena Crocuta crocuta spelaea (Goldfuss 1823) population, their excrements and prey from the late Pleistocene hyena den of the Sloup Cave in the Moravian Karst, Czech Republic. Hist. Biol. 24, 161-185.

Djamali, M., de Beaulieu, J.-L., Shah-Hosseini, M., Andrieu-Ponel, V., Amini, A., Akhani, H., Leroy, S.A.G., Stevens, L., Alizadeh, H., Ponel, P., Brewer, S., 2008. An Upper Pleistocene long pollen record from the near east, the $100 \mathrm{~m}$-long sequence of Lake Urmia, NW Iran. Quat. Res. 69, 413e420.

Dehghani, M., Djamali, M., Gandouin, E., Akhani, H., 2017. A pollen rain - vegetation study along a $3600 \mathrm{~m}$ mountain - desert transect in the Irano-Turanian region; implications for the reliability of some pollen ratios as moisture indicators. Rev. Palaeobot. Palynol. $247,133-149$

Djamali, M., Biglari, F., Abdi, K., Akhani, H., Andrieu-Ponel, V., de Beaulieu, J.-L., Mashkour, M., Ponel, P., 2011. Pollen analysis of coprolites from a late Pleistocene-Holocene cave deposit (Wazmeh Cave, W Iran): A glance at the glacial vegetation and flora of central Zagros Mountains. J. Archaeol. Sci. 38, 3394-3401.

Doostmohammadi, M., Malekmohammadi, M., Djamali, M., Akhani, H., 2019. Is Pteropyrum a pathway to $\mathrm{C}_{4}$ evolution in Polygonaceae? An integrative approach to the taxonomy and anatomy of Pteropyrum $\left(\mathrm{C}_{3}\right)$, an immediate relative of Calligonum $\left(C_{4}\right)$. Bot. J. Linn. Soc. 192, 369-400.

Dray, S., Dufour, A.-B., Thioulouse, J., 2020. Package 'Ade4': Analysis of Ecological Data: Exploratory and Euclidean Methods in Environmental Sciences. URL. https://cran.r-project.org/web/packages/ade4/index.html.

Firouz, E., 2005. The Complete Fauna of Iran. I.B. Tauris, New York

Fourvel, J.-B., Fosse, P., 2017. Conives (Indre, France): Un nouvel exemple de repaire d'hyènes du pléistocène supérieur. Quaternaire $28,455-469$.

Fourvel, J.-B., Mwebi, O., 2011. Hyenas' level of dependence on livestock in pastoralist areas in the Republic of Djibouti and Kenya: relation between prey availability and bone consumption sequence. In: Brugal, J.-P. (Ed.), Prédateur dans tous leurs états. Evolution, Biodiversité, Interactions, Mythes, Symboles. XXXI ${ }^{\mathrm{es}}$ rencontres internationales d'archéologie et d'histoire d'Antibes. APDCA, Antibes, pp. 157-176.

Fourvel, J.-B., Fosse, P., Avery, G., 2015. Spotted, striped or brown? Taphonomic studies at dens of extant hyenas in eastern and southern Africa. Quat. Int. 369, 38-50.

Ghirshman, R., 1938-1939. Fouilles de Sialk près de Kashan 1933,1934,1937. 2 vol.. Librairie Orientaliste Paul Geuthner, Paris.

Guijarro, J.A., 2019. Package 'climatol': climate tools (series homogenization and derived products). URL. https://cran.r-project.org/web/packages/climatol/index.html.

Hernández-Ledesma, P., Berendsohn, W.G., Borsch, T., Mering, S., Akhani, H., Arias, S., Castañeda-Noa, I., Eggli, U., Eriksson, R., Flores-Olvera, H., Fuentes-Bazán, S., Kadereit, G., Klak, C., Korotkova, N., Nyffeler, R., Ocampo, G., Ochoterena, H., Oxelman, B., Rabeler, R.K., Sanchez, A., Schlumpberger, B.O., Uotila, P., 2015. A taxonomic backbone for the global synthesis of species diversity in the angiosperm order Caryophyllales. Willdenowia 45, 281-384.

Heydari, S., Ghasidian, E., Conard, N.J., 2009. Iranian Paleolithic sites on travertine and tufa formations. In: Otte, M., Biglari, F., Jaubert, J. (Eds.), Recent Research on Paleolithic of Iran, Proceedings of the XV World Congress UISPP, Lisbon, BAR International Series 1968. 28. Archaeopress, Oxford, pp. 109-124.

Horwitz, L.K., Goldberg, P., 1989. A study of Pleistocene and Holocene Hyaena coprolites. J. Archaeol. Sci. 16, 71-94.

Hunt, A.P., Lucas, S.G., 2019. Hyena hegemony: Biogeography and taphonomy of Pleistocene vertebrate coprolites with description of a new mammoth coprolite ichnotaxon. Ichnos 27, 111-121.
Husson, F., Josse, J., Le, S., Mazet, J., 2020. Package ‘FactoMineR': Multivariate Exploratory Data Analysis and Data Mining. URL. https://cran.r-project.org/web/packages/ FactoMineR/index.html

Ilkhani, H., Livarda, A., Fazeli Nashli, H., 2019. Archaeobotanical report about Tappeh Sialk, North Mound. First Impressions. In: Nokandeh, J., Curtis, J., Pic, M. (Eds.), Tappeh Sialk the Glory of Ancient Kashan. Iranian Heritage Foundation, Louvre, Richt, National Museum of Iran, pp. 40-44.

Juggins, S., 2019. Package 'Rioja': Analysis of Quaternary Science Data. URL. https://cran.rproject.org/web/packages/rioja/index.html.

Karami, M., Riazi, B., Kalani, N., 2006. Habitat evaluation of the striped hyena (Hyaena hyaena hyaena) in Khojir National Park. Environ. Sci. 11, 77-86 (In Persian with English abstract)

Kassambara, A., 2020. Package 'Factoextra': Extract and Visualize the Results of Multivariate Data Analyses. URL. https://cran.r-project.org/web/packages/factoextra/index. html.

Klein, J.-C., 1994. La végétation altitudinale de l'Alborz Centrale (Iran). Institut Français de Recherche en Iran, Tehran.

Kolowski, J.M., Katan, D., Theis, K.R., Holekamp, K.E., 2007. Daily patterns of activity in the spotted hyena. J. Mammal. 88, 1017-1028.

Marean, C.W., Kim, S.Y., 1998. Mousterian large-mammal remains from Kobeh cave. Behavioral implications for Neanderthals and early modern Humans. Curr. Anthropol. 39, 79-113.

Mashkour, M. 2004a. Paleo-environmental studies in Sialk (Kashan). In: Shahmirzadi, M. (Ed.), The Silver Smith of Sialk, Report No. 2. Iranian Cultural Heritage and Handicraft and Tourism Organization, Tehran, pp. 189-194 (In Persian).

Mashkour, M., 2004b. Preliminary report of archaeozoological studies of the third season of the Sialk Reconsideration Project. In: Shahmirzadi, M. (Ed.), The potters of Sialk, Report No. 3. Iranian Cultural Heritage and Handicraft and Tourism Organization, Tehran, pp. 95-108 (In Persian)

Mashkour, M., Fahimi, H., 2019. Iron Age animal exploitation at the edge of the Dasht-e Kavir, central desert of Iran. The case of Shamshirgah (Qom-Iran). In: Hassanzadeh, Y., Vahdati, A., Karimi, Z. (Eds.), Proceedings of the International Conference on the Iron Age in Western Iran and Neighbouring Regions, Vol 1. Iranian Cultural Heritage and Handicraft and Tourism Organization, Tehran, pp. 191-200.

Mashkour, M., Monchot, H., Trinkhaus, E., Reyss, J.-L., Biglari, F., Bailon, S., Heydari, S., Abdi, K., 2008. Carnivores and their prey in the Wezmeh Cave (Kermanshah, Iran): A late Pleistocene refuge in the Zagros. Int. J. Osteoarchaeol. 19, 678-694.

Mashkour, M., Bon, C., Demeter, F., Friess, M., Sheikhi, S., Huet, L., Thomas, L., 2019. Tappeh Sialk Human and Animal Osteological Collections at the National Museum of Natural History. In: Nokandeh, J., Curtis, J., Pic, M. (Eds.), Tappeh Sialk the Glory of Ancient Kashan. Iranian Heritage Foundation, Louvre, Richt, pp. 45-55p National Museum of Iran.

Mohamed Ahmed, F.A, Takona, N.Y., Yousif, R.A., Mohamed Salih, R.R., 2011. Some behavioral traits of striped hyaena under captive conditions. J Life Sci. Biomed 2, 196-199.

Monchot, H., 2008. Des hyènes tachetées au Pléistocène supérieur dans le Zagros (grotte Wezmeh, Iran). Archaeozoology of the Near East VIII, TMO 49. Maison de l'Orient et de la Méditerranée, Lyon, pp. 65-78.

Monchot, H., Mashkour, M., 2010. Hyenas around the city (Kashan, Iran). J. Taphon. 8, $17-32$.

Moore, P.D., Webb, J.A., Collinson, M.E., 1991. Pollen Analysis. 2nd ed. Blackwell, Oxford.

Oksanen, J., Blanchet, G., Friendly, M., Kindt, R., Legendre, P., McGlinn, D. Minchin, P.R. O'Hara, R.B., Simpson, G.L., Solymos, P., Stevens, M.H.M., Szoecs, E., Wagner, H., 2019. Ordination Methods, Diversity Analysis and Other Functions for Community and Vegetation Ecologists. URL. https://cran.r-project.org/web/packages/vegan/ index.html.

Pearson, S., Betancourt, J.L., 2002. Understanding arid environments using fossil rodent middens. J. Arid Environ. 50, 499-511.

Podlech, D., 1986. Artemisia, [Compositae VI - Anthemideae]. In: Rechinger, K.-H. (Ed.), Flora Iranica. Vol. 158, pp. 159-223 Graz.

Podlech, D. 2013. Some remarks on Artemisia subgenus Serephidium (Asteraceae) mostly from Afghanistan. Rostaniha 14, 48-58.

Reille, M., 1992. Pollen et spores d'Europe et d'Afrique du Nord. Laboratoire de botanique historique et de palynologie, Marseille.

Reille, M., 1995. Pollen et spores d'Europe et d'Afrique du Nord, Supplément 1. Laboratoire de botanique historique et de palynologie, Marseille.

Reille, M., 1998. Pollen et spores d'Europe et d'Afrique du Nord, Supplément 2. Laboratoire de botanique historique et de palynologie, Marseille.

Rezaei, S., Naderi, S., Karami, P., 2017. The ecological study of striped hyaena (Hyaena hyaena) denning areas in the Haftad Oolleh protected Area, Arak, Iran. Nat. Environ. 70, 351-362.

Rieger, I., 1979. A review of the biology of the striped hyenas, Hyaena hyaena (Linne, 1758). Saugetierkundliche Mitteilungen 27, 81-95

Rivas-Martínez, S., Rivas Sáenz, S., Penas, A., 2011. Worlwide bioclimatic classification system. Global Geobotany 1, 1-634.

RStudio Team, 2015. RStudio: Integrated Development for R. RStudio, Inc, Boston, MA URL. http://www.rstudio.com/.

Scott, L., 2000. Pollen. In: Partridge, T.C., Maud, R.R. (Eds.), The Cainozoic of Southern Africa. Oxford Monographs on Geology and Geophysics No. 40. Oxford Univ. Press, Oxford, pp. 339-350.

Scott, L., Fernández-Jalvo, Y., Carrión, J., Brink, J., 2003. Preservation and interpretation of pollen in hyaena coprolites: Taphonomic observations from Spain and southern Africa. Palaeont. Afr. 39, 83-91.

Scott, L., Rossouw, L., Cordova, C., Risberg, J., 2016. Palaeoenvironmental context of coprolites and plant microfossils from Unit II. Azokh 1. In: Fernández-Jalvo, Y., King, T. Yepiskoposyan, L., Andrews, P. (Eds.), Azokh Cave and the Transcaucasian Corridor Springer, Dordrecht, pp. 287-295. 
Shamoon, H., Shapira, I., 2019. Limiting factors of Striped Hyaena, Hyaena hyaena, distribution and densities across climatic and geographical gradients (Mammalia: Carnivora). Zool. Middle East 65, 189-200.

Shirazi, Z., Tengberg, M., 2012. Vegetation and wood exploitation at Tape Sialk from the Neolithic to the Iron Age. In: Shahmirzadi, S.M. (Ed.), The Villagers of Sialk. Research Center of Iranian Cultural Heritage, Handicrafts and Tourism Organization, Tehran, pp. 17-26.

Singh, P., Gopalaswamy, A.M., Karanth, K.U., 2010. Factors influencing densities of striped hyenas (Hyaena hyaena) in arid regions of India. J. Mammal. 91, 1152-1159.

Singh, R., Qureshi, Q., Sankar, K., Krausman, P.R., Goyal, S.P., Nicholson, K.L., 2014. Population density of striped hyenas in relation to habitat in a semi-arid landscape, western India. Acta Theriol. 59, 521-527.

Stockmarr, J., 1971. Tablets with spores used in absolute pollen analysis. Pollen Spores 13 615-621.

Tengberg, M., 2004. Archaeobotanical analysis at Tepe Sialk. Results from the 2003/04 season. In: Shahmirzadi, M.S. (Ed.), The Potters of Sialk. Sialk Reconsideration Project No. 3, pp. 25-32.
Tourani, M., Moqanaki, E.M., Kiabi, B.H., 2012. Vulnerability of striped hyaena, Hyaene hyaena, in a human-dominated landscape of central Iran. Zool. Middle East 56 133-136.

Turnbull, P.F., 1975. The mammalian fauna of Warwasi Rock Shelter, West-central Iran. Fieldiana Geol. 33, 141-155.

van Zeist, W., Bottema, S., 1977. Palynological investigations in western Iran. Palaeohistoria 19, 19-85.

van Zeist, W., Bottema, S., van der Veen, M., 2001. Diet Vegetation at Ancient Carthage, the Archaeobotanical Evidence. Groningen Institute of Archaeology, Groningen.

Wagner, A.P., 2006. Behavioral ecology of the striped hyena (Hyaena hyaena). Unpublished Ph.D. Thesis. Montana State University, Bozeman, U.S.A.

Xiong, H., Shi, A., Mou, B., Qin, J., Motes, D., Lu, W., Ma, J., Weng, Y., Yang, W., Wu, D., 2016 Genetic diversity and population structure of cowpea (Vigna unguiculata L. Walp). PLoS ONE 11, e0160941. https://doi.org/10.1371/journal. pone.0160941.

Yll, R., Carrión, J.S., Marra, A.C., Bonfiglio, L., 2006. Vegetation reconstruction on the basis of pollen in Late Pleistocene hyena coprolites from San Teodoro Cave (Sicily, Italy). Palaeogeogr. Palaeoclimatol. Palaeoecol. 237, 32-39. 